\title{
Risk factors for syphilis in young women attending a family health program in Vitória, Brazil
}

\author{
Fatores de risco para sífilis, em mulheres jovens, atendidas pelo programa de \\ saúde da família em Vitória (ES), Brasil
}

\section{Angélica Espinosa Miranda ${ }^{1}$ \\ Valdir Monteiro Pinto ${ }^{3}$ \\ Sinésio Talhari ${ }^{5}$}

\author{
Nínive Camilo Figueiredo ${ }^{2}$ \\ Kimberly Page ${ }^{4}$
}

Abstract: BACKGROUND: The high prevalence of STDs among women indicates the need to implement approaching techniques, case detection and prevention of new cases.

Oвјестіvеs: To describe the frequency of risk factors for syphilis and assess attitudes towards sexual risk in a population of young women in Vitória, ES.

MEтHODS: Cross-sectional, population-based study, performed in Vitória. Interviews were held and VDRL and MHA-TP were investigated in blood samples.

REsulTs: Among the 904 eligible women (18-29 years) sampled from the Family Health Program (FHP), 11 were diagnosed with syphilis, a prevalence of $1.2 \%$ (CI95\% 0.5-1.9). Median age was 23 years (interquartile range 20-26 years); $65.7 \%$ of participants were in high school or college and $85.4 \%$ lived with their family or sexual partner. Factors associated with syphilis included: lower educational level ( $<8$ years of schooling) [Adjusted Odds Ratio aOR=4.3 (CI 95\% 1.01-17.99)]; >1 lifetime sexual partners $[(\mathrm{aOR})=6.50(\mathrm{CI} 95 \% 1.37-30.82)]$, and history of a previously diagnosed STD $[\mathrm{aOR}=10.3$ (CI95\% 2.3744.33)]. Two thirds $(67.7 \%)$ of the women surveyed agreed that it is not easy to tell their sexual partner they do not want to have sex without condoms; $52.3 \%$ thought it is difficult to use condoms in all sexual intercourses, and $36.2 \%$ said they cannot do anything if their partner refuses to use condoms.

Conclusions: Using the FHP as an approach to perform routine VDRL can contribute to decreasing the vulnerability of these women and help control congenital syphilis.

Keywords: Family health program; Risk factors; Sexually transmitted diseases; Syphilis; Treponemal infections; Women's health

Resumo: Fundamentos: A prevalência elevada de DST entre as mulheres indica a necessidade de implementação de abordagem, de detecção de casos e de prevenção de novos agravos.

OвJETivo: descrever a frequência dos fatores de risco para sífilis e as percepções de risco sexual, em mulheres jovens, na cidade de Vitória, ES.

MÉToDos: Estudo populacional, em corte-transversal, por amostragem, realizado em Vitória. Foram realizadas entrevista e pesquisa de VDRL e MHA-TP em amostra de sangue.

RESULTADOS: Entre as 904 mulheres elegíveis (18-29 anos) selecionadas pelo Programa de Saúde da Família (PSF), 11 foram diagnosticadas com sífilis sendo a prevalência de 1,2\% (IC95\% 0,5-1,9). A mediana de idade foi de 23 anos (distância interquartil de 20-26 anos); 65,7\% das participantes alcançavam o ensino médio ou superior e 85,4\% moravam com a família ou com o parceiro sexual. Fatores associados com a sífilis: menor nível educacional (<=oito anos de estudo) [Odds ratio ajustado $($ Ora $)=4,3$ (IC95\% 1,01-17,99)]; ter tido mais de um parceiro na vida $[$ ORa=6,50 (IC95\% 1,37-30,82)] e história prévia de DST $[\mathrm{ORa}=10,3$ (IC95\% 2,37-44,33)]. Dois terços $(67,7 \%)$ das mulheres entrevistadas relataram não achar fácil dizer ao parceiro que não fará sexo sem preservativo, $52,3 \%$ consideram difícil usar preservativo em todos os intercursos sexuais e $36,2 \%$ acham que não há o que fazer, se o parceiro recusar usar preservativo.

CONCLUSõES: A utilização do PSF como porta de entrada para a realização do VDRL, na rotina de atendimento, pode contribuir para diminuir a vulnerabilidade destas mulheres e ajudar no controle da sífilis congênita.

Palavras-chave: Doenças sexualmente transmissíveis; Fatores de risco; Infecções por treponema; Programa saúde da família; Saúde da mulher; Sífilis

\footnotetext{
Received on 29.10.2010.

Approved by the Advisory Board and accepted for publication on 21.12.2010

* Work performed at the Universidade Federal do Espírito Santo (UFES) - Vitória (ES), Brasil

Conflict of interest: None / Conflito de interesse: Nenbum

Suporte financeiro / Financial funding: Financial Support: AIDS International Training in Research Program (Fogarty International Center) D43W00003 and ICOHRTA Brazil Scientist Program (Fogarty International Center) D43TW005799

PhD in Public Health - Teacher at the Universidade Federal do Espírito Santo (UFES) - Vitória (ES), Brasil.

Master in Infectious Diseases - Physician at the Epidemiologic Surveillance of the City Council - Vitória - Vitória (ES), Brasil.

Master in Public Health - Manager of the STD Unit of the Department of STD /Aids and viral hepatitis - Brasília (DF), Brasil.

PhD in Public Health - Researcher of Department of Epidemiology and Biostatistics, University of California, San Francisco (UCSF) - California, USA.

PhD in Dermatology - President Director of the Fundação de Medicina Tropical do Amazonas (FMTAM) - Manaus (AM), Brasil. 


\section{INTRODUCTION}

After the advent of the human immunodeficiency virus (HIV) infection, the control of sexually transmitted disease (STDs) became a priority, as it was demonstrated that the prevention and control of these infections represent a unique opportunity to improve the sexual and reproductive life of women. ${ }^{1}$ The high prevalence of STD among women indicates the need to implement approaching methods, case detection and prevention of new cases. ${ }^{2}$

Syphilis, an infection caused by the Treponema pallidum, is a sexually transmitted disease which is still an important public health problem in many countries. ${ }^{3,4}$ Pregnancy is more common in young women. Syphilis, during the gestational period, has serious implications for the woman and the foetus, as it can cause abortion, intra-uterine death, neonatal death or severe sequelae for the newborn. ${ }^{5,6}$ The transmission of the Treponema pallidum occurs from the pregnant woman to the foetus, via the placenta, at any moment during the gestation.

Biologic, psychiatric and social factors can increase the vulnerability of adolescents and young people to STDs. From the biologic point of view, the cylindrical epithelium of the cervix in young women is more exposed. ${ }^{8}$ Young age at menarche can be a cause of early start of sexual activity, increasing the probability of contamination. ${ }^{9}$ From the psychic point of view, adolescence and youth are periods of definition of a sexual identity, with experimentation and change of partners. The feeling of invulnerability make these people believe they are invulnerable, and they expose themselves to risks without foreseeing the consequences. ${ }^{10}$

The Family Health Program's (FHP) strategy has a fundamental role in approaching the health of these women, acting on early identification and diagnosis. The main objective of the FHP is to reorganize the attention to health in a new framework, substituting the traditional model and bringing health closer to the family and, this way, improving the quality of life of these people. ${ }^{10}$

The absence of data on the behavioural pattern of young women living on the health districts of the city of Vitoria in terms of syphilis, seen by the FHP people, was the reason to perform this study aiming at assessing the situation and planning intervention strategies for the population. The objectives of the study were to identify the epidemiologic and clinical factors related to syphilis and to describe the perceptions in terms of the risks of acquiring STDs and the infection rate of the disease in young women in this city.

\section{METHODS}

This study is part of a project designed to assess the prevalence of infection by the HIV, syphilis, hepatitis $\mathrm{B}$ and $\mathrm{C}$ markers and associated risk behaviour in young women (18-29 years) in Vitória, ES. It was a population-based study, by sampling, in three health districts of the city, where the FHP was already implemented, and which had a complete list of the domiciles. ${ }^{11}$ In this article factors related to the presence of syphilis infection and the perception in terms of risk of acquiring STDs were specifically discussed.

Sample constitution: The enrolment list of the FHP included 10.660 women between 18 and 29 years who lived on the districts described below. Using a random numbers table a sample of 1.200 women was obtained. The size of the sample was calculated to estimate the prevalence rate of HIV, with a confidence interval of $95 \%$, on the population studied and was based on the calculation of a prevalence rate of HIV of $0,8 \%$ in pregnant women resident in Vitória, which generated a number of 990 women. ${ }^{12}$ The HIV was used as a reference because it is the infection with the lowest prevalence. Considering a loss of $20 \%, 1.200$ women were selected. The target population was composed of young women living in the city of Vitória for at least six months. The Vitória Health Department is administratively divided into seven health districts. From these districts, the district I (Continental), II (Maruípe), and VI (São Pedro) were selected as the targets because they represented three different social strata of the population, which was seen and properly enrolled at the FHP. The total population of the studied areas was, at the time, 117.056, from which $10.660(9,1 \%)$ were women aged between 18 and 29 years. The sample had $30,7 \%$ of women from the Continental District, 51\% from Maruípe and 18,3\% from São Pedro, as these percentages represented the proportion of women, within the age bracket, in each district, in relation to the total of residents of the city districts. The contact was done at the selected women's residences and the data collection was performed by the FHP nurses, during the period of March to December, 2006.

Questionnaire: It consisted of a face-to-face interview based on the questionnaire used on the The Young Women's Survey research. ${ }^{13}$ The questionnaire was validated and the questions that gave information about: a) socio-demographic data (age, schooling, occupation, marital status and income); b) clinical data (history of STD, clinical complaints, contraception, pregnancy and abortions); c) information about sexual practice and risk behaviour (use of condom, number of sexual partners, prostitution, sexual abuse, use of alcohol and drugs, blood transfusion) were kept. All the questions were closed.

Laboratory tests: VDRL (Venereal Disease 
Research Laboratory) tests with confirmation by MHATP (Micro-hemagglutination for Treponema pallidum) were done. The tests were done by the Central Laboratory of the Municipal Health Secretariat of Vitória, according to the manufacturer's instructions.

Data analysis: The statistical analysis was done using the SPSS version $\mathbf{1 1 . 5}$ for Windows. Initially a descriptive analysis was done, including frequency distribution for the qualitative variables, calculation of average and standard deviation for the quantitative variables. The prevalence of syphilis was estimated by the frequency of positive tests, and the correspondent confidence interval was calculated for $95 \%$. The possible association between syphilis and risk behaviour and demographic and clinical variables were tested using the chi-square test. Odds Ratio and confidence intervals were calculated to estimate the level of association between the infection and potential risk factors. Multivariate analysis of logistic regression were used to estimate the effect of having a positive test for syphilis at the same time that other predictive variables were controlled.

Ethical aspects: This project was submitted to and approved by the Research Ethics Committee of the Centro de Ciências da Saúde of the Universidade Federal do Espírito Santo and by the Research Ethics Committee of the University of California, San
Francisco. All women who consented to participate on the project were informed about the objectives of the research, signed a Free and Explained Consent Form and received medical care when diagnosed with the infection.

\section{RESULTS}

Amongst the 1.200 women selected, 1.029 participated on the study, which represents $85,7 \%$ of the sample initially selected. From those, 904 reported sexual activity and were included on the study. The prevalence of syphilis was $1,2 \%$ (CI 95\% 0,5-1,9). The median age was 23 years (interquartile distance (IQD) of $20-26$ years). Approximately $66 \%$ of the young women attended middle or tertiary school and $85,4 \%$ lived with their family or sexual partner. When comparing with the women without syphilis infection, those diagnosed with syphilis had lower schooling level (2, $6 \%$ vs. $0,5 \%, p=0,01)$. The demographic data are described on table 1 .

Five women $(0,6 \%)$ reported the use of injectable drugs, but none of them was diagnosed with syphilis. The behavioural data, described on table 2 , showed that $87,7 \%$ reported having had only one sexual partner for the past six months and 36, 5\% reported the use of condom on the last sexual intercourse.

Previous history of STD, spontaneous abortion

TABLE 1: Socio-demographic characteristics and association with syphilis in young women seen at the Family Health program in Vitória, $2006(\mathrm{~N}=904)$

\begin{tabular}{|c|c|c|c|}
\hline Variables & Total N (\%) & Syphilis N (\%) & OR $(95 \% \mathrm{CI})$ \\
\hline \multicolumn{4}{|l|}{ Age in years } \\
\hline 18 to 24 years & $557(61,6)$ & $5(0,9)$ & $1,9(0,59-6,41)$ \\
\hline 25 to 29 years & $347(38,4)$ & $6(1,7)$ & 1 \\
\hline \multicolumn{4}{|l|}{ Schooling } \\
\hline Fundamental school & $310(34,3)$ & $8(2,6)$ & $5,2(1,38-19,81)$ \\
\hline Middle/Tertiary school & $594(65,7)$ & $3(0,5)$ & 1 \\
\hline \multicolumn{4}{|l|}{ Marital status } \\
\hline Single/separated/widow & $492(54,4)$ & $5(1,0)$ & $1,4(0,44-4,75)$ \\
\hline Married/de facto & $412(45,6)$ & $6(1,5)$ & 1 \\
\hline \multicolumn{4}{|l|}{ Housing } \\
\hline Family/partner & $772(85,4)$ & $9(1,2)$ & $0,8(0,16-3,59)$ \\
\hline Friends/boarding/others & $132(14,6)$ & $2(1,5)$ & 1 \\
\hline \multicolumn{4}{|l|}{ Paid work } \\
\hline Yes & $412(45,6)$ & $6(1,5)$ & $0,7(0,21-2,29)$ \\
\hline No & $492(54,4)$ & $5(1,0)$ & 1 \\
\hline \multicolumn{4}{|l|}{ Monthly income } \\
\hline Up to 4 minimum wages & $615(68,0)$ & $7(1,1)$ & $1,2(0,35-4,20)$ \\
\hline More than 4 minimum wages & $289(32,0)$ & $4(1,4)$ & 1 \\
\hline
\end{tabular}


and HIV and HBsAg positive tests were associated with syphilis. The history of previous STD was more frequent in women with syphilis when compared with those with negative test $(5,5 \%$ vs. $0,6 \%, p=0,001)$ (Table 3). Amongst the clinical complaints reported during the interview, the most frequent was vaginal discharge in $302(33,4 \%)$, followed by pelvic pain 195 $(21,6 \%)$, vaginal pruritus $110(12,2 \%)$, burning sensation when urinating $92(10,2 \%)$, genital warts $22(2$, $4 \%)$ and genital ulcers 15 (1, 7\%).

The final logistic regression model showed an association between syphilis and the following variables: having up to eight years of schooling [adjusted OR=4,3 (IC95\% 1,01-17,99)]; having had more than one sexual partner over a lifetime [adjusted OR $=6,50$ (IC95\% 1,37-30,82)] and previous history of STD [adjusted OR $=10,3$ (IC95\% 2,37-44,33)].

In terms of risk perception to STD/Aids, it is worth stressing out that two thirds of the women $(67,7 \%)$ do not think it is easy to tell their partners they will not have sex without condom, 52,3\% considered it hard to use condom during all sexual intercourses and $36,2 \%$ think there is nothing to do if the partner refuses to use condom (Table 4).

\section{DISCUSSION}

In this study, data about young women, aged between 18 and 29 years, resident in three administrative health districts of the city of Vitória, seen at the FHP, were analysed. The participation rate was high $(85,7 \%)$. The prevalence of syphilis found $(1,2 \%)$ is in accordance with that described by the last national sentinel study in pregnant women. ${ }^{14}$ Some studies done in young and pregnant women, in Brazil, reported prevalence rates of syphilis varying from $0,8 \%$ to $1,6 \%$ which are in accordance with the one found in this study. ${ }^{15-17}$ However, there are still some studies reporting higher prevalence rates of syphilis in different areas of Brazil, which shows the importance of control strategies for this infection in young women in order to prevent congenital syphilis. ${ }^{18,19}$ The variation of these rates found in various studies needs to be monitored to assess the quality of health care available, in special in terms of sexual and reproductive health, on the various services of the country.

In 1995, by the resolution CE 116.R3 of the Pan-

TABLE 2: Behavioural characteristics and association with syphilis in young women seen at the Family Health program in Vitória, $2006(\mathrm{~N}=904)$

\begin{tabular}{|c|c|c|c|}
\hline Variables & Total N (\%) & Syphilis N (\%) & OR $(95 \% \mathrm{CI})$ \\
\hline \multicolumn{4}{|c|}{ Sexual partners on the last six months } \\
\hline More than one & $793(87,7)$ & $10(1,3)$ & $1,4(0,18-11,08)$ \\
\hline One & $111(12,3)$ & $1(0,9)$ & 1 \\
\hline \multicolumn{4}{|c|}{ Lifetime sexual partners } \\
\hline More than one & $609(67,4)$ & $5(1,7)$ & $1,73(0,52-5,73)$ \\
\hline One & $295(32,6)$ & $6(1,0)$ & 1 \\
\hline \multicolumn{4}{|c|}{ Use of condom on the last sexual intercourse } \\
\hline No & $574(63,5)$ & $7(1,2)$ & $1,0(0,29-3,46)$ \\
\hline Yes & $330(36,5)$ & $4(1,2)$ & 1 \\
\hline \multicolumn{4}{|c|}{ History of sexual abuse } \\
\hline Yes & $80(8,9)$ & $1(1,3)$ & $1,0(0,13-8,12)$ \\
\hline No & $821(91,1)$ & $10(1,2)$ & 1 \\
\hline \multicolumn{4}{|c|}{ History of prostitution } \\
\hline Yes & $12(1,3)$ & $1(8,3)$ & $8,0(0,94-68,14)$ \\
\hline No & $892(98,7)$ & $10(1,1)$ & 1 \\
\hline \multicolumn{4}{|c|}{ Anal sex practice } \\
\hline Yes & $90(10,0)$ & $1(1,1)$ & $1,1(0,14-8,77)$ \\
\hline No & $814(90,0)$ & $10(1,2)$ & 1 \\
\hline \multicolumn{4}{|c|}{ Use of illicit drugs } \\
\hline Yes & $163(18,0)$ & $6(3,7)$ & $5,6(1,70-18,66)$ \\
\hline No & $741(82,0)$ & $5(0,7)$ & 1 \\
\hline
\end{tabular}


American Health Organization, of which Brazil is a signatory with other countries from Latin America and the Caribbean, a compromise was reached to eliminate congenital syphilis from the Americas. ${ }^{20}$ Achieving this goal will only be possible when the early diagnosis is made a priority and the adequate treatment of young women and their sexual partners is secured. Despite the recommendation by the Ministry of Health that the test for syphilis is offered to all pregnant women on the first antenatal consultation and at the beginning of the third trimester, and the development of campaigns for the elimination of congenital syphilis from the country, this infection remains as a frequent threat during the gestational period, even with the existence of low cost and accurate tests and the sensibility of the Treponema pallidum to penicillin, a medication also cheap and available on the Unified Health System. ${ }^{21,22,23}$

The socio-demographic data from the women included in the study reflect the characteristics of young women, seen at the FHP on the health districts of the city of Vitoria, which is constituted by low middle class, middle and middle high class women, with access to school and public health services and who have, in the majority, middle school level.

The face-to-face interview might have generated an underestimation of the results due to the prejudi- ce and the fear of these young women in answering some questions about sexual behaviour. The possibility of directed questions, because of the tendency to generate socially acceptable answers, should not be ignored. Some imprecise answers might have happened in terms of condom use, age of first sexual relation and number of sexual partners. Additionally, this sample has the peculiarity of showing a schooling level and average family income superior to those of the Brazilian population. However the results seem to be in accordance with the data from the research about Sexual Behaviour of the Brazilian Population and Perception of HIV/AIDS, where 13, $4 \%$ and 16, 1\% of young people between 20 to 24 years and 25 to 29 years reported having already used some type of drug, $92,3 \%$ had already started sexual life on the age bracket between 20 to 24 years and 35, $4 \%$ reported regular use of condom. ${ }^{24}$ On the present study, from the s 1.029 women interviewed, $18 \%$ had history of illicit drugs, $85,7 \%$ had already started sexual activity and $63,5 \%$ reported the use of condom on the last sexual intercourse. The percentage of previous STD history was high, despite access to information about sexuality, contraception, STD/Aids, and the high proportion of use of condom on the last sexual intercourse. This data is in accordance with the results from the research done by the Brazilian Centre of Analysis and

TABLE 3: Clinical characteristics and association with syphilis in young women seen at the Family Health Program in Vitória, 2006 ( $\mathrm{N}=904)$

\begin{tabular}{|c|c|c|c|}
\hline Variables & Total N (\%) & Syphilis N (\%) & OR (95\%CI) \\
\hline \multicolumn{4}{|c|}{ History of STD } \\
\hline Yes & $109(12,1)$ & $6(5,5)$ & $9,2(2,76-30,69)$ \\
\hline No & $795(87,9)$ & $5(0,6)$ & 1 \\
\hline \multicolumn{4}{|c|}{ Previous pregnancy } \\
\hline Yes & $557(61,3)$ & $8(1,4)$ & $1,7(0,44-6,34)$ \\
\hline No & $347(38,4)$ & $3(0,9)$ & 1 \\
\hline \multicolumn{4}{|c|}{ Spontaneous abortion } \\
\hline Yes & $152(16,8)$ & $6(3,9)$ & $6,1(1,85-20,38)$ \\
\hline No & $752(83,2)$ & $5(0,7)$ & 1 \\
\hline \multicolumn{4}{|c|}{ Gynaecological exam on the previous 3 years } \\
\hline No & $156(17,3)$ & $1(0,6)$ & $2,1(0,27-16-53)$ \\
\hline Yes & $748(82,7)$ & $10(1,3)$ & 1 \\
\hline \multicolumn{4}{|c|}{ HIV positive test } \\
\hline Yes & $5(0,6)$ & $1(20,0)$ & $22,2(2,28-216,90)$ \\
\hline No & $899(99,4)$ & $10(1,1)$ & 1 \\
\hline \multicolumn{4}{|c|}{ HbsAg positive test } \\
\hline Yes & $7(0,8)$ & $1(14,3)$ & $14,8(1,63-134,34)$ \\
\hline No & $897(99,2)$ & $10(1,1)$ & 1 \\
\hline
\end{tabular}


TABLE 4: Risk perception of DST/Aids in young women seen at the Family Health Program in Vitória, $2006(\mathrm{~N}=904)$

\begin{tabular}{|c|c|c|c|}
\hline Variables & Disagree N (\%) & Agree $\mathbf{N}(\%)$ & Do not know $N(\%)$ \\
\hline $\begin{array}{l}\text { I think it is easy to tell the partner that I will not have } \\
\text { sex without condom }\end{array}$ & $272(30,1)$ & $611(67,6)$ & $21(2,3)$ \\
\hline I think it is hard to use condom all the time & $399(44,1)$ & $473(52,3)$ & $32(3,5)$ \\
\hline Using condom does not bring satisfaction & $546(60,4)$ & $316(35,0)$ & $42(4,6)$ \\
\hline $\begin{array}{l}\text { If someone with whom I am having sex does } \\
\text { not use condom, there is not much I can do }\end{array}$ & $530(58,6)$ & $327(36,2)$ & $47(5,2)$ \\
\hline I think oral sex in not real sex & $551(61,0)$ & $276(30,5)$ & $77(8,5)$ \\
\hline The sexual act is only dangerous when there is vaginal sex & $704(77,9)$ & $145(16,0)$ & $55(6,1)$ \\
\hline The sexual act is only dangerous when there is anal sex & $650(71,9)$ & $185(20,5)$ & $69(7,6)$ \\
\hline $\begin{array}{l}\text { The risk of transmission of HIV by oral sex is very small } \\
\text { and I am willing to have this risk }\end{array}$ & $682(75,4)$ & $116(12,8)$ & $106(11,7)$ \\
\hline HIV positive individuals under treatment have & $568(62,8)$ & $178(19,7)$ & $158(17,5)$ \\
\hline \multicolumn{4}{|l|}{ smaller chance of transmitting the HIV } \\
\hline $\begin{array}{l}\text { If I got infected with HIV today there would be a good } \\
\text { chance for the cure of AIDS be discovered even before I got sick }\end{array}$ & $532(58,8)$ & $207(22,9)$ & $165(18,3)$ \\
\hline $\begin{array}{l}\text { If I exposed myself to HIV today I could use a medication } \\
\text { to prevent the infection }\end{array}$ & $441(48,8)$ & $296(32,7)$ & $167(18,5)$ \\
\hline I do not care if I am infected by HIV & $868(96,0)$ & $17(1,9)$ & $19(2,1)$ \\
\hline
\end{tabular}

Planning which indicates that, currently, young people have their first sexual intercourse earlier than previous generations, but the level of knowledge about STD/Aids does not alter a risky sexual behaviour. ${ }^{24}$

Variables like: lower schooling (having up to eight years of schooling), having had more than one lifetime sexual partner and previous history of STD were facts independently associated with syphilis infection in this study. Other studies done in Vitória and Brazil have also demonstrated the importance of low schooling, previous history of STD and sexual behaviour, like not using condom in the presence of STD in young women. ${ }^{12,18,19}$

In terms of perceptions of the use of condom and the risk of transmission of the AIDS virus it was observed that, independently of the level of schooling, the knowledge about forms of transmission and the perception of the susceptibility to the infection, there are still some reticence against the use of condom in a general way. Despite the significant percentage of young people reporting that they think it is easy to tell the partner they will not have sex without condom, $(67,6 \%)$, it was also high the report of the difficulty in using condom in all sexual intercourses $(52,3 \%)$ and of not having an option when the partner refuses to use it $(36,2 \%)$. In terms of the answers received about risk perception of aids, it was noted that the percentage of doubt in relation to some questions is still high.

The results found here show the importance of the implementation of services of counselling and assistance to sexual and reproductive health, and that they should be directed, specifically, to this population group. Despite the need of more and better information about health for the population, the cultural and institutional barriers make educational programs on risky sexual behaviour for young women difficult. ${ }^{25,26}$

Educational programs directed at young people should include some key elements in order to succeed: education and information to young people of both sexes about the practice of safe sex, the preven- 
tion of STD and Aids, the facilitation of counselling in terms of testing for syphilis, hepatitis and HIV, the need for treatment of the sexual partner in terms of STD in order to break the transmission chain. Add to that the facilitation of the treatment of syphilis on the health unit itself and the compulsory notification of pregnant women in order to better monitor the cases and prevent congenital syphilis. The health programs should be wide ranging, encompassing young people and their sexual partners and other members of the community, like educators and health professionals. ${ }^{27}$ Another important aspect to be emphasized is that the introduction of more efficient methods of approaching STD will not be, in itself, efficient in controlling these diseases if women continue not to have access to the medication and the practical and emotional support needed for prevention and treatment.

\section{CONCLUSION}

The elimination of congenital syphilis will only be possible when the early diagnosis is made a priority and the adequate treatment of the women and their sexual partners is secured. Keeping in mind that the population in this study is assisted by the FHP, it is important to establish joint strategies with the participation of members of the health team in order to obtain a better result on the control of STDs.

Control measures include, amongst others, the tracking of the STDs, the VDRL testing as part of the routine care of sexually active young women, as well as a friendly dialogue with these youngsters with emphasis on health promotion by means of acts of information, education and communication, aiming at reducing the vulnerability of them to STDs. 


\section{REFERENCES}

1. Fleming DT, Wasserheit JN. From epidemiological synergy to public health policy and practice: the contribution of other sexually transmitted diseases to sexual transmission of HIV infection. Sex Transm Infect. 1999; 75:3-17.

2. Thiessen C, Ssekubugu R, Wagman J, Kiddugavu M, Wawer MJ, Emanuel E, et al. Personal and community benefits and harms of research: views from Rakai, Uganda. AIDS. 2007; 21:2493-501.

3. Hook EW 3rd, Peeling RW. Syphilis Control - A Continuing Challenge. Lancet. 2004; 351:122-4.

4. Avelleira JCR, Bottino G. Sífilis: diagnóstico, tratamento e controle. An Bras Dermatol. 2003;81:111-26.

5. Wendel GD. Gestational and congenital syphilis. Clin Perinatol 1988; 15:287-303.

6. Hira SK, Bhat GJ, Chikamata DM, Nkowane B, Tembo G, Perine PL, et al. Syphilis intervention in pregnancy: Zambian demonstration project. Genitourin Med. 1990; 66:159-64.

7. Sánchez PJ, Wendel GD. Syphilis in pregnancy. Clin Perinatol. 1997; 24:71-90.

8. Grant LM. Adolescent sexuality. Pediatr Clin North Am. 1988; 35:1271-89.

9. Adih WK, Alexander CS. Determinants of condom use to prevent HIV infection among youths in Ghana. J Adolesc Health. 1999;24:63-72.

10. Ministério da Saúde. Secretaria de Assistência à Saúde. Departamento de Atenção Básica (DAB). [Internet]. Evolução do credenciamento e implantação da estratégia Saúde da Família. Brasília; 2004 [acesso 11 Ago. 2009]. Disponível em: http://dtr2004.saude.gov.br/dab/localiza_cadastro.php

11. Miranda AE, Figueiredo NC, Schmidt R, Page-Shafer K. A population-based survey of the prevalence of HIV, syphilis, hepatitis B and hepatitis C infections and associated risk factors among young women in Vitória, Brazil. AIDS Behav. 2008; 12(4 Suppl):S25-31.

12. Miranda AE, Alves MC, Neto RL, Areal KR, Gerbase AC. Seroprevalence of HIV, hepatitis $B$ virus, and syphilis in women at their first visit to public antenatal clinics in Vitória, Brazil. Sex Transm Dis. 2001; 28:710-3.

13. Ruiz JD, Molitor F, McFarland W, Klausner J, Lemp G, Page-Shafer K, et al. Prevalence of HIV infection, sexually transmited diseases, and hepatitis and related risk behavior in young women living in low-income neighborhoods of northern California. West J Med. 2000;172:368-73.

14. Szwarcwald CL, Barbosa-Junior A, Miranda AE, Paz LC. Resultados do estudo sentinela-parturiente, 2006: desafios para o controle da sífilis congênita no Brasil. J Bras Doenças Sex Transm. 2007;19:128-33.

15. Figueiró-Filho EA, Senefonte FR, Lopes AH, de Morais 00, Souza Júnior VG, Maia $\mathrm{TL}$, et al. Frequency of HIV-1, rubella, syphilis, toxoplasmosis, cytomegalovirus, simple herpes virus, hepatitis B, hepatitis C, Chagas disease and HTLV I/II infection in pregnant women of State of Mato Grosso do Sul. Rev Soc Bras Med Trop. 2007;40:181-7.

16. Olbrich Neto J, Meira DA. Soroprevalência de vírus linfotrópico de células $T$ humanas, vírus da imunodeficiência humana, sífilis e toxoplasmose em gestantes de Botucatu - São Paulo, Brasil: fatores de risco para vírus linfotrópico de células T humanas. Rev Soc Bras Med Trop. 2004, 37:28-32.
17. Rodrigues CS, Guimarães MDG; Grupo Nacional de Estudo sobre Sífilis Congênita. Positividade para sífilis em puérperas: ainda um desafio para o Brasil. Rev Panam Salud Pública. 2004;16:168-75.

18. Benzaken AS, García EG, Rodrigues AO, Mora C, Sanchez MS, Sardinha JC. "Madre Fronteriza": estudo conjunto de prevalência de sífilis tricomoníase e HIV em gestantes da tríplice fronteira do Alto Rio Solimões. DST J Bras Doenças Sex Transm. 16:15-23, 2004.

19. Lima LHM, Viana MC. Prevalência e fatores de risco para a infecção por HIV, sífilis, hepatite $B$, hepatite $C$ e HTLV-I/II em parturientes e gestantes de baixa renda atendidas na Região Metropolitana de Vitória, Espírito Santo, Brasil. Cad Saúde Pública. 2009;25:668-76.

20. Ministério da Saúde. Secretaria de Vigilância em Saúde. Programa Nacional de DST E AIDS. Diretrizes para o controle da sífilis congênita. Brasília: Ministério da Saúde; 2005. 52p. Série Manuais, n. 62.

21. Rotta O. Diagnóstico sorológico da sífilis. An Bras Dermatol. 2005;80:299-302.

22. Ministério da Saúde. Secretaria de Vigilância em Saúde. Programa Nacional de DST e Aids. Manual de Controle das Doenças Sexualmente Transmissíveis. Brasília: Ministério da Saúde; 2006. 140p. Série Manuais, n. 68.

23. Ministério da Saúde. Secretaria de Vigilância em Saúde. Boletim Epidemiológico eletrônico. Avaliação da notificação da sífilis congênita no Brasil, 2000 a 2003. Ano 07, n. 07, 2007.

24. Ministério da Saúde. Centro Brasileiro de Análise e Planejamento. Comportamento sexual da população brasileira e percepções sobre HIV e AIDS. Brasilia: Ministério da Saúde; 2000. Série Avaliação 4.

25. Ruzany MH, Peres EM, Meirelles ZV, Calazans ML, Grossman E, Kuschnir MC, et al. Multidisciplinary training program in the field of integral care for adolescents. Educ Med Salud. 1995;29:112-8.

26. de Codes JS, Cohen DA, de Melo NA, Teixeira GG, Leal Ados S, Silva Tde J, et al. Screening of sexually transmitted diseases in clinical and non-clinical settings in Salvador, Bahia, Brazil. Cad Saúde Pública. 2006; 22:325-34.

27. Gevelber MA, Biro F. Adolescents and sexually transmitted diseases. Pediatr Clin North Am. 1999;46:747-66.

How to cite this article/Como citar este artigo: Miranda AE, Figueiredo NC, Pinto VM, Page K, Talhari S. Risk factors for syphilis in young women attending a family health program in Vitória, Brazil. An Bras Dermatol. 2012; 87(1):76-83. 


\section{Erratum}

\section{Errata}

The errata refers to "Risk factors for syphilis in young women seen through the family healthcare program in Vitoria (ES), Brazil." An Bras Dermatol. 2012;87:76-83.

"In table 2 , the resulting data about the number of sexual partners over the last six months is reversed. The correct is $87.7 \%$ of the women reported having had a single partner over the last six months. In table 3, with regard to the perceptions of risk for STD/AIDS, two thirds of the women $(67.7 \%)$ do not think it's easy to tell their partners they will not have intercourse without a condom. The word "not" is missing. The data in the result section were correctly described." 